\title{
O LAICATO A PARTIR DO DOCUMENTO DE APARECIDA
}

The Laity in the Document of Aparecida

João Décio Passos *

RESUMO: A temática do leigo é central no Documento de Aparecida. Herdeira da eclesiologia conciliar e ancorada na realidade latino-americana, a concepção de leigo da V Conferência afirma o povo de Deus como condição fundamental de todos os cristãos; entende que todos os cristãos são discípulos missionários convocados ao anúncio entusiasta de Jesus Cristo na sociedade atual e reafirma a missão dos leigos como sujeitos eclesiais na Igreja e no mundo. A reflexão indica também os limites de Aparecida em relação à questão: ausência de uma crítica ao clericalismo e às divisões internas dos leigos na Igreja e carência de uma teologia da laicidade.

PALAVRAS-CHAVE: Conferência de Aparecida. Igreja. Leigo. Povo de Deus.

ABSTRACT: Laity is a key theme of the Aparecida Document. The layperson's conception of the Fifth Conference is a legacy of conciliar ecclesiology and well anchored in the reality of Latin America. The document asserts that the people of God is the very condition of all Christians and understands that all Christians are missionary disciples called to announce Jesus Christ with enthusiasm in today's society. It also reaffirms the mission of lay men and women as ecclesial subjects in the Church and in the world. However, the article also indicates Aparecida's limitations regarding the absence of a critique of clericalism and of the laity's internal division within the Church, as well as the lack of a theology of secularism.

KEYWORDS: Aparecida Conference. Church. Laity. People of God.

* Pontifícia Universidade Católica de São Paulo, São Paulo, SP, Brasil. 


\section{Introdução}

temática do leigo é, de fato, central na eclesiologia que foi sendo Adesenvolvida há quase um século na Igreja católica. Nesse período, aconteceu uma virada copernicana na autocompreensão da Igreja que passou, gradativamente, de um modelo centrado na hierarquia para um modelo de corpo comum feito de diversidades. A questão do leigo foi um vetor central nessa virada, seguindo um movimento centrípeto: primeiramente pela afirmação da legitimidade eclesial da atuação do leigo na sociedade moderna (Leão XIII) e, em seguida, pela incorporação do leigo dentro da Igreja como constitutivo da própria Igreja e não somente como mero pertencente ou paciente do clero (Pio XII). Esse movimento narra, de fato, uma sequência histórica verificável: a emergência do sujeito moderno $\Rightarrow>$ a emergência do sujeito social católico dentro da sociedade $\Rightarrow>$ a emergência do sujeito dentro da Igreja. A história renova a teologia e a própria Igreja. Verdade tão antiga quanto nova, mas também pouco lembrada pelos amantes do tradicionalismo. Por conseguinte, a teologia do laicato mostra-se como um componente central presente no cerne da eclesiologia renovada que vai sendo desenvolvida no século passado e que culmina no Concilio Vaticano II.

O leigo é, desde então, uma questão eclesial fundamental por constituir a maioria do povo de Deus, como hoje reafirma Francisco, assim como por significar a presença da Igreja no mundo. Ainda mais: na condição leiga e laica se encontram aqueles sujeitos construtores da sociedade, cristãos ou não, crentes ou não. De fato, a sociedade moderna, tecnocientífica e tecnocrata, é conduzida, em boa medida, por leigos e não por clérigos, mas é conduzida sobretudo por sujeitos laicos com os quais os leigos atuam e são chamados a dialogar.

Exercitar esse olhar de fora para dentro - da sociedade para a Igreja ainda é um desafio teológico para a Igreja atual, mesmo após a teologia do mundo tão presente no Vaticano II. Mas, é possível perceber ainda a urgência do tema do leigo, tendo em vista as dificuldades concretas encontradas dentro da Igreja, sobretudo quando se depara com o clericalismo que desvirtua e deforma não somente Igreja em sua condição fundamental, mas também a própria ação específica do laicato na Igreja e no mundo.

Qual será a contribuição de Aparecida perante esse quadro tão fundamental e urgente? A reflexão será encaminhada em três momentos principais: uma aproximação da questão do leigo no Documento, tendo em vista os aspectos semânticos e a moldura geral onde o conceito se insere, um apontamento da teologia do laicato e do ministério leigo e a indicação de possíveis silêncios de Aparecida em relação ao leigo e sua missão. As considerações finais perguntam sobre os frutos de Aparecida na Igreja atual. Vale lembrar que a análise foca diretamente no texto do Documen- 
to e visa explicitar os conteúdos ali presentes; objetiva expor, portanto, a teologia do laicato do DAp e não compor uma sistematização teológica da temática a partir do mesmo. Por essa razão metodológica, as fontes textuais do Magistério ocupam lugar central na reflexão, dispensando um balanço bibliográfico sobre o assunto.

\section{Questão conceitual}

A noção de leigo presente nas decisões de Aparecida deve ser situada primeiramente no conjunto do Documento. Trata-se de uma noção que, por sua natureza eclesiológica, se mostra transversal no sistema teológico que rege toda a reflexão nos três momentos em que está disposta: no ver, no julgar e no agir. Nesse sentido, pode-se dizer que o momento do ver foca na realidade vivenciada e protagonizada pelos leigos nos seus aspectos positivos e negativos, nas luzes e sombras. O momento do julgar foca na realidade comum do povo de Deus, a partir da qual se elevam as diferenças ministeriais, os serviços e os compromissos. O momento do agir tem, por sua vez, o leigo como um sujeito primordial, à medida que entende haver uma urgência na transformação da realidade latino-americana inserida no mundo globalizado em todos os seus aspectos (BRIGHENTI, 2007).

Esse conceito fundamental de leigo, dissolvido no conjunto dos ensinamentos de Aparecida, é expressão de uma concepção eclesiológica que tem o Vaticano II como epicentro. O povo de Deus é a condição básica que faz todos serem Igreja de Jesus Cristo e comunhão de membros no mesmo Corpo. Trata-se, portanto, de um dado eclesial evidente. O primeiro de natureza quantitativa, sendo a imensa maioria dos membros da Igreja composta por leigos, como bem lembra o Papa Francisco (EG, n. 102). O segundo de natureza eclesiológica: a condição fundamental da Igreja concretiza-se na condição leiga. Todos são inseridos na Igreja como cristãos, antes de qualquer função que possa distinguir os cristãos. Mas, pode-se igualmente pensar em um dado pastoral: a presença do leigo no mundo, entendida como sua missão primordial, desde o Concílio Vaticano II (AA, n. 7). O agir da Igreja na sociedade e na cultura tem no leigo o sujeito eclesial principal (PASSOS, 2014, p. 109-190).

Será necessário também situar a noção de leigo dentro de um regime semântico mais amplo, feito de conceitos mais gerais e de conceitos mais específicos. Nesse caso, o leigo se insere necessariamente na noção mais ampla de povo de Deus, batizados e cristãos. E se desdobra em noções mais específicas, como trabalhadores, mulheres, pobres, ministérios etc. Haveria também que destacar as noções correlatas à de leigo como o coletivo laicato e a de sujeito eclesial, a mais definida. Do ponto de vista de uma teologia atual do laicato, apresenta-se ainda a noção central do 
Documento: discípulos missionários. Ainda seria interessante verificar as noções que escondem ou negam o leigo em seu significado e em sua ação e instauram precisamente o seu reverso: como a de clero ou de hierarquia, mas, sobretudo, a que esconde e revela uma preocupação com a relevância eclesial do leigo como clericalismo ou de laicismo. Por certo, esse sistema conceitual feito de distintas conotações e de várias conexões revela e reforça a importância da temática nas decisões de Aparecida. Mas, ao mesmo tempo, exige opções de leitura que serão inevitavelmente limitadas. Nesse sentido, a abordagem permanecerá na esfera mais geral da compreensão de leigo, tendo em vista a base eclesiológica onde a questão se ancora.

\section{A moldura geral de Aparecida}

De fato, em estreita continuidade com o Vaticano II, pode-se dizer que a temática do leigo goza de uma centralidade no Documento de Aparecida. O termo leigo aparece 49 vezes no Documento e leiga 21 vezes. Mas, em primeiro lugar o leigo tem um significado teológico fundamental, como povo de Deus que define todos os cristãos, antes de qualquer distinção ministerial. A condição leiga é a condição eclesial mais básica. Todos se tornam Igreja como leigos, no caso, sinônimo de cristãos e batizados. ${ }^{1}$ Todos pertencem ao povo de Deus, comunidade de batizados e membros do Corpo de Cristo. Essa eclesiologia encontra no Concílio seu ponto de chegada e seu ponto de partida, quando recolhe as reflexões e orientações que antecedem ao grande evento, as reflexões eclesiológicas de Yves Congar (eclesiologia total) (CONGAR, 1966, p. 7) e a eclesiologia anterior de Pio XII (Igreja como Corpo místico) ${ }^{2}$, assim como a longa experiência de atuação do laicato na Ação Católica. Nessa concepção, o leigo compõe a parcela mais ampla da Igreja e é portador da dignidade mais fundamental, aquela que diz respeito à própria inserção no Corpo de Cristo e no sacerdócio comum e, no fim, aquela condição que salva. Recordemos mais uma vez Santo Agostinho retomado em Lumen gentium: "Atemoriza-me o que sou para vós, alegra-me o que sou convosco. Para vós sou bispo, convosco sou cristão. Ser bispo é um dever, ser cristão é uma graça. Ser bispo é um perigo, ser cristão é salvação" (n. 32).

Em Aparecida a condição leiga está inserida nessa eclesiologia da igualdade e da dignidade fundamental, antes de qualquer distinção de ordem, de serviço ou de poder. É de dentro dessa condição básica que emergem as

\footnotetext{
${ }^{1}$ Cf. Carta do Papa Francisco ao Cardeal Marc Oullet. In: PONTIFÍCIA COMISSÃO PARA A AMÉRICA LATINA. O indispensável compromisso dos leigos na vida publica dos países latino-americanos, p. 11.

${ }^{2}$ Encíclica Mistici corporis Christi de 29 de junho de 1943.
} 
distinções de serviço e não o contrário. Ha diversidade de funções dentro do mesmo Corpo, como ensina o Apóstolo Paulo (1 Cor 12-15). As distinções que historicamente adquiriram sempre maior nitidez existem para servir o conjunto do povo de Deus. Ao tratar dos ministros ordenados a Constituição Lumen gentium afirma que todos os ministérios se destinam "ao bem de todo o corpo" e "estão a serviço dos irmãos" em função da salvação de todo o povo de Deus (n. 18). Qualquer teologia da "emanação descendente do sagrado" que começa no topo e termina na base, onde jaz passivamente o povo sem as dignidades sagradas, peca contra a teologia da comunhão mística do Corpo de Cristo, unidade na diversidade, contra a teologia do povo de Deus e do sacerdócio comum dos batizados (VELASCO, 1996, p. 227-322).

Aparecida recepciona esse ensinamento focando na condição comum de todos os batizados, feitos por essa razão "discípulos e missionários". O Capitulo I denominado Os discípulos missionários coloca esse sujeito coletivo como condição comum a partir da qual falam os padres da $\mathrm{V}$ Conferência. O discurso é construído com dois sujeitos ocultos: os bispos falando na condição de discípulos missionários (n. 22) e falando como conjunto da Igreja (n. 23ss). Essa oscilação discursiva é reveladora de uma consciência eclesial real nos padres ali presentes: todos somos Igreja, todos somos discípulos missionários, todos somos povo de Deus, todos somos servidores etc. Essa consciência, embora tenha sido construída numa longa duração, expressa a postura não hierarcocêntrica do episcopado, mas, ao contrário a postura de pertença e de serviço ao povo de Deus. Diz a Lumen gentium: "Cristo nosso Senhor com o fim de apascentar o povo de Deus (...) instituiu na Igreja vários ministérios que se destinam ao bem de todo o corpo" (n. 18).

Por essas razões e munido dessas conotações pode-se enunciar uma hipótese a ser verificada: a da centralidade do leigo no Documento de Aparecida. E pelas razões já expostas, seria uma centralidade natural. O leigo é o sujeito coletivo fundamental que compõe a Igreja, a partir do qual falam os bispos e sujeito principal para o qual também fala diretamente a Conferência. $\mathrm{O}$ leigo seria, portanto, o ponto de partida eclesial e o ponto de chegada da ação da Igreja na sociedade atual.

Mas, é necessário pensar agora na função do leigo na Igreja, mais precisamente no ministério leigo, distinto em vários aspectos dos ministérios ordenados. O leigo tem uma condição e uma missão que lhe são próprias. A Lumen gentium depara-se com essa necessidade, ao abrir o Capítulo sobre os leigos. Reconhece que o Capítulo sobre o Povo de Deus (Capitulo II) vale para os leigos, mas é necessário dirigir uma palavra específica para aqueles fieis que têm o "nome de leigos". Os padres conciliares parecem manifestar o velho incômodo em relação ao termo "leigo" (n. 30). No número seguinte repetem o inevitável: a definição negativa do 
leigo, nome dado aos fiéis cristãos que não possuem uma "ordem sacra" (n. 31). Sintomaticamente, Aparecida faz uma recepção dessa definição conciliar retirando, entretanto, dela somente a parte positiva, que define o leigo a partir do que ele é. Diz que os fiéis leigos "são os cristãos que estão incorporados a Cristo pelo batismo, que formam o povo de Deus e participam das funções de Cristo; sacerdote, profeta e rei. Realizam, segundo sua condição, a missão de todo o povo cristão na Igreja e no mundo" (n. 209). Essa positividade é significativa e contorna a conotação pejorativa - ao menos eclesialmente - dada ao leigo: aquele a quem falta algo. Desde o Vaticano II, é necessário afirmar que ao leigo não falta nada em termos cristãos. São portadores da condição mais fundamental, da dignidade fundamental e da missão fundamental de discípulo missionário.

\section{A Igreja e o mundo como espaços constitutivos do leigo}

Aparecida situa-se na temporalidade de recepção do Concilio Vaticano II no continente, precisamente na cadeia de recepções que se estende desde Medellín. As quatro Conferências levaram adiante a intenção originante do Vaticano II de fazer o aggiornamento da Igreja. De fato, a cada década esse aggiornamento buscou os meios de efetivar-se nos diferentes contextos que demarcavam a vida de nossos povos, nações e Igrejas. E não será necessário lembrar a função hermenêutica desses contextos no momento de construção das reflexões e decisões dos padres conferencistas em cada uma das assembleias. Portanto, nas Conferências anteriores a temática do leigo se fez presente: a partir da teologia do leigo compreendido membro da Igreja, como portador da dignidade fundamental do ser cristão e como sujeito ativo convocado a agir na sociedade (Lumen gentium e Apostolicam actuositatem). A ação do leigo no mundo não é somente um lugar primordial de sua atuação, mas o lugar a partir de onde a Igreja fala na busca de sua missão em cada tempo e espaço.

Nesse sentido, é importante verificar a relação direta entre a temática do leigo e a situação de pobreza e injustiça do continente nas decisões de Medellín. O Documento inicia o Capítulo 10 falando do "compromisso dos leigos no campo da Justiça e da Paz"; relembra a situação de "marginalidade, alienação e pobreza" condicionada por uma dependência econômica e afirma o "compromisso libertador e humanizador" dos leigos nessa realidade. Não por acaso, o leigo é o primeiro sujeito eclesial a que se dirigem os padres, vindo em seguida, os Sacerdotes e os Religiosos. Puebla inverte essa ordem colocando o leigo na sequência do Ministério hierárquico e da Vida Consagrada (n. 659-777). Os bispos fazem aí uma avaliação da atuação do leigo na Igreja e no mundo desde Medellín, detectando as dificuldades encontradas nesses dois âmbitos. Puebla reafirma 
a missão do leigo como agente transformador da situação da realidade de "opressão e marginalização" (n. 778). Santo Domingo foca na evangelização e na cultura; parte da Igreja para chegar ao mundo. O leigo é um agente evangelizador. Introduz a questão dizendo que: "Hoje, como sinal dos tempos, vemos um grande número de leigos comprometidos com a Igreja que exercem diversos ministérios, serviços e funções nas comunidades eclesiais de base ou atividades nos movimentos eclesiais" (n. 95). O leigo está inequivocamente posicionado na relação entre a Igreja-sociedade; é o sujeito que faz o vínculo natural e efetivo entre as duas realidades. E a visão de realidade posiciona o leigo dentre os demais ministérios eclesiais com seu perfil específico: agente transformador, testemunho, missionário, profissional etc.

Nessa perspectiva, cabe, portanto, a pergunta pelo contexto de Aparecida. A resposta pode ser localizada no fundo e em tópicos específicos do Documento nas seguintes constatações: o mundo globalizado onde se insere o continente com seus persistentes dramas humanos, a cultura correspondente a esse mundo, a saber, sempre mais individualizada e centrada no consumo e no bem-estar, a reprodução eclesial dessa cultura em posturas de individualismo religioso, a cultura plural que abriga o decréscimo de católicos e de cristãos, assim como os trânsitos religiosos, a desproporção entre o crescimento populacional e o crescimento de católicos e de ministérios ordenados e religiosos.

Essa situação coloca a Igreja em uma postura de urgência evangelizadora e a faz buscar em seu carisma original as energias e as referências capazes de colocar todos em ação, sem demora e com entusiasmo. A Igreja é missionária. Todos somos discípulos missionários. Todos os discípulos são portadores de um dom que deve ser acolhido e transmitido com alegria. O leigo é visto como sujeito central nessa tarefa. E para isso deve ser formado como discípulo destemido a levar o Evangelho em todos os lugares e dimensões da vida. Não por acaso, o Documento faz 11 referências à temática da formação do laicato.

O contexto de Aparecida é o mundo globalizado que possui uma dimensão estrutural (como sistema econômico que configura uma situação de injustiça planetária) e uma dimensão cultural (o indivíduo inserido nas dinâmicas de consumo e na cultura de bem-estar). O Documento busca, portanto, expor as raízes e as dinâmicas de um processo de mudança que engloba coletividade e individualidade, aspectos que são reproduzidos no interior da vida da Igreja.

O conceito discípulos missionários parece encaixar-se com coerência nesse contexto em que é necessário falar ao coletivo da Igreja, mas também a cada sujeito cristão. Todos somos discípulos missionários e cada um é discípulo e missionário. Pode-se dizer que esse conceito eclesial integra 
possíveis polarizações entre um comunitarismo religioso que esconde os indivíduos e o individualismo religioso que dispensa a vida comum. A noção de sujeito eclesial responde social e politicamente por esse posicionamento integrador do coletivo com o individual. Aparecida fala a todos e a cada leigo em seu convite insistente à evangelização.

\section{A teologia e o ministério do leigo em Aparecida}

A teologia do laicato de Aparecida inserida na lógica geral das reflexões participa do que se poderia chamar de "síntese" no sentido dialético do termo. Essa síntese pode ser vista em alguns aspectos: a) Metodológico: as reflexões recolhem a tradição anterior do método ver, julgar e agir e, por conseguinte, a afirmação da realidade como ponto de partida da reflexão (Medellín e Puebla, mas, antes a própria Gaudium est spes) e recolhem a abordagem cristocêntrica ponto de partida de Santo Domingo, bem como sua preocupação evangelizadora, agora centrada na ação missionária; b) Estrutural: as reflexões sintetizam, ainda, as dimensões social e eclesial com a dimensão individual: cada um é sujeito eclesial e, por conseguinte, social. Supera, assim, as leituras estruturais centradas no coletivo, assim como as leituras centradas no polo individual; c) Eclesiológico: faz uma síntese da eclesiologia conciliar quando adota o povo de Deus como condição fundamental (Lumen gentium), a dimensão do serviço ao mundo e aos mais pobres (Gaudium et spes), a missão da Igreja no mundo (Ad gentes), a ação do laicato na sociedade (Apostolicam actuositatem). As Igrejas da América Latina foram, de fato, um canteiro de ação-reflexão que recolheram os frutos da tradição passada e incorporaram os desafios presentes, produzindo na dor do tempo e das contradições históricas, frutos maduros, sínteses teológicas e pastorais.

Nesse patamar de síntese, certamente tecida inseparavelmente no labor histórico e no labor do Espírito, pode-se verificar em Aparecida um ensinamento sobre o laicato nos seguintes aspectos: a) afirmação da tradição eclesiológica do Vaticano II; b) afirmação da relatividade da Igreja; c) delimitação da noção povo de Deus; d) afirmação da noção de sujeito eclesial; e) colocação da missão primordial do leigo. Não se trata propriamente de um conteúdo inovador em termos de tradição que se arranca desde o Concílio, mas de enfoques novos que insistem em aspectos específicos da visão e atuação do laicato na Igreja e no mundo.

\section{a) A tradição eclesiológica do Vaticano II}

O leigo como povo de Deus constitui uma tradição consolidada desde o Concílio, tradição que vai sendo recepcionada nas Conferências latino-americanas (COMBLIN, 2002). Pode-se ver nessa tradição uma era do 
laicato. Mantendo a tradição católica que distingue cristãos ordenados de cristãos em geral, o Vaticano II resolveu eclesiologicamente a natureza do leigo à medida que instituiu a teologia da Igreja a partir de seu conjunto, superando a compreensão hierarcológica (Congar) que a definia como sinônimo de hierarquia. A Igreja é o conjunto do povo de Deus e a comunhão dos distintos fiéis no mesmo Corpo. Nessa comunidade todos são inseridos pelo batismo e participam do tríplice múnus de Jesus Cristo. Para o serviço desse conjunto são instituídos os ministérios ordenados e não ordenados. Essa comunidade é sacramento da salvação no mundo, servidora da humanidade e dialogante com as realidades históricas. A partir dessa doutrina do leigo como sujeito cristão pleno, eclesialmente completo e ministerialmente habilitado, podem-se buscar as especificidades da teologia do laicato. Essa eclesiologia adquire contornos próprios na realidade latino-americana como Igreja encarnada, comunidade local, pequenas comunidades e Igreja ministerial.

\section{b) A relatividade da Igreja}

O eixo teológico-analítico discípulos missionários afirma de modo explícito a posição relativa da Igreja em relação a sua fonte, o Cristo vivo na história, e o mundo, lugar de sua ação missionária. Nessa postura, a Igreja encontra sua razão de ser, sua natureza crística e sua energia centrífuga. Ser discípulo é configurar-se permanentemente ao Mestre. Mas além desse absoluto há um imperativo da ação: o mundo presente. É para o mundo que todo discípulo é lançado como missionário. Não se separa o discipulado da missão e vice-versa. Portanto, do ponto de vista eclesiológico há duas tarefas performativas para a compreensão da Igreja: sua conformidade com Cristo e sua inserção no mundo. Viver do Cristo vivo é discernir o mundo, levar o Cristo ao mundo e trazer o mundo a ele. A origem e o fim é o próprio Cristo. A meta do mundo é ser Reino de Deus. Entre esses absolutos situa-se a Igreja.

\section{c) Delimitação do povo de Deus}

Essa eclesiologia é acolhida e definida em Aparecida precisamente com a noção de discípulo missionário. Nesse sentido, pode-se falar em uma originalidade eclesiológica na V Conferência. Essas duas realidades inseparáveis, discipulado e missionaridade, delimitam eclesialmente a teologia Povo de Deus, enquanto sujeito eclesial coletivo fundamental, destacando aspectos que poderiam ser definidos como síntese das eclesiologias conciliares: ser discípulo missionário constitui uma dinâmica eclesial que explicita aspectos da teologia do laicato: a) A referência cristocêntrica: todos somos discípulos de Jesus Cristo e, portanto, seus seguidores imediatos. O Documento carrega essa afirmação de fé em todo o seu conjunto como se pode observar nos próprios títulos; b) a referência subjetiva: cada fiel 
é discípulo e missionário. Supera-se qualquer noção coletiva que remeta a uma generalidade que esconde o sujeito individual. Pode-se ver aqui a adoção de um conceito atual afirmado como central no processo de modernização. Mas, todos são discípulos missionários na condição de Igreja. O conceito engloba as duas dimensões da vida eclesial: a comunitária e a individual, sem que haja sobreposição de uma sobre a outra. c) Sujeito eclesial: a Igreja é feita de vários sujeitos eclesiais. Esse conceito utilizado para definir o leigo na Igreja (n. 497) cobra consequências: consciência, autonomia e ação dentro e fora da Igreja. Ser sujeito eclesial é não ser delegado ou autorizado por alguém a exercer essa postura e essa missão, uma vez que se trata de um estado decorrente da própria condição cristã.

\section{d) Missão primordial do leigo}

O discípulo missionário é sujeito que atua na Igreja e no mundo. Das ocorrências do termo leigo, 14 dizem respeito à sua ação no mundo, 5 dizem respeito à ação interna nas comunidades eclesiais e 3 referentes à ação organizada dos leigos. Essa compreensão de que o lugar primordial da ação do leigo é a sociedade, é herdeira de uma tradição de longa temporalidade e não deixa de carregar ainda hoje possíveis ambiguidades se não for bem compreendida. Pode esconder um dualismo entre as dimensões ad intra e ad extra eclesiais, um dualismo entre clero e leigo, ou o pior, um falso dualismo que isola o clero da ação no mundo, como lugar de perigo, embora todos estejam a serviço do Reino que visa precisamente transformar a história. Pode ainda revelar uma compreensão pré-conciliar que afirmava ser o leigo o braço da hierarquia no mundo, um sujeito auxiliar situado como tarefeiro no mundo sob a condução do clero.

O Vaticano II, embora afirme ser a sociedade o lugar primordial da ação dos leigos, o faz sem reproduzir os antigos dualismos pré-conciliares. O leigo é a Igreja no mundo. Aparecida fala em "homens da Igreja no coração do mundo e homens do mundo no coração da Igreja" (n. 209). Não há razões teológicas nessa prioridade de ação social do leigo, mas um princípio realista, tendo em vista a imensa maioria dos cristãos serem leigos, e um princípio estratégico, por atuarem como sujeitos profissionais na sociedade. A delimitação do mundo como lugar fundamental de atuação do leigo não advém de qualquer posição subalterna que ocupa na Igreja, mas, pelo contrário, de seu ser Igreja inserido na sociedade do ponto de vista social, político e profissional. A ação no mundo decorre do fato de ser Igreja no mundo. $\mathrm{O}$ leigo é um sujeito histórico, ou seja, alguém consciente, autônomo e ativo no contexto em que se encontra. O leigo é um sujeito cultural (n. 51), as minorias sociais são sujeitos construtores da história (n. 97), a Igreja tem a missão de educar os excluídos para serem sujeitos (n. 385, 394 e 407) e a escola deve educar para construir sujeitos capazes de assenhorar-se de sua história (n. 330). A noção de sujeito designa um ideal eclesial, ético e político 
e uma tarefa educadora para a Igreja: comunidade plasmadora de sujeitos e criadora de criadores, discípula que faz discípulos. Mas essa noção deixa também desafios para as ações concretas do leigo a partir da Igreja como indivíduo/grupo autônomo, mas não isolado ou independente, como agentes criativos comunitariamente inseridos e como artífices capazes de interpretar a realidade e nela intervirem por convicção e decisão próprias.

\section{Limites de Aparecida}

Falar em limites das orientações de Aparecida não significa negar seu valor normativo como magistério local e nem depreciar o alcance de seus ensinamentos. Significa precisamente avaliar suas orientações a partir da ótica que adota (sempre limitada a uma perspectiva) e a partir das próprias fontes de onde bebe (de modo particular o Vaticano II). Nesse sentido, podem-se verificar duas ausências ou limites no Documento.

\section{a) Do ponto de vista da perspectiva eclesiológica}

A positividade real e verdadeira dos discípulos missionários apresenta-se como convocação urgente e chamado a uma adesão entusiasta à Boa Notícia de Jesus Cristo em um mundo que se torna menos religioso e menos humano e em uma Igreja que decresce em números de adeptos e de ministros ordenados. O dom do discipulado e da missionaridade, a saída imediata para o testemunho e a transformação focam, sobretudo, na fonte e no fim da Igreja. O leigo é o mediador privilegiado nessa transitividade permanente da Igreja de Jesus Cristo para a sociedade. A afirmação teológica desse dom e dessa missão não foca nos desafios reais de concretização e de realização dos mesmos dentro da Igreja. Sem negar a verdade dessa postura eclesial, há que considerar a ausência de uma autocrítica eclesial das condições de possibilidade de realização da missão do leigo, onde o clericalismo se mostra como entrave realíssimo, assim como os conflitos internos de grupos eclesiais.

\section{- O clericalismo}

Conferências anteriores reconheceram essa dificuldade nas práticas eclesiais (Puebla, n., 784; S. Domingo, n. 96). O clericalismo é um entrave ao exercício próprio do ministério leigo, sujeito eclesial que goza de autonomia para exercer sua missão, autonomia que deve ser reconhecida pelos ministérios ordenados (GS, n. 43; PP, n. 81; Medellín, 10, II, 9; 10, I,5). Mas, é também um equívoco eclesiológico que peca contra o corpo de Cristo feito de unidade de todos na diversidade de ministérios. Clericalismos de diferentes vieses crescem hoje na Igreja, ignorando a origem a função de todos os ministérios, sejam aqueles que distinguem numa falsa ontologia 
cristã os sagrados dos profanos, sejam os que se julgam donos da Igreja, sejam os que se mostram mestres e superiores ou, ainda, os que se exibem como magos espetaculares. Há que afirmar, sem dúvidas, que essa doença eclesial é transversal; se faz presente em atitudes de ministros ordenados e de ministros leigos. São os casos dos leigos mais clericais que os padres. Nesse espírito, cresce certa tendência eclesial em que leigos que se agregam em grupos de identidade confusa. Muitos desses grupos almejam precisamente alcançar o estado clerical, buscam status canônico que os distinguem de outros movimentos ou adotam modelos estéticos clericais, como que negando a própria condição leiga que os define eclesialmente. É forçoso observar que Aparecida silencia sobre essa questão, tanto ao tratar das sombras da Igreja (n. 100) quanto ao tratar dos presbíteros (n. 191-204) e dos próprios leigos (n. 209-215).

\section{As divergências internas}

Não há dúvidas de que as diferentes formas de organização e ação do laicato geram dificuldades de ação conjunta e coordenada dentro da Igreja. Aparecida não dá destaque a essa problemática eclesial concreta. Os movimentos e novas comunidades afirmam-se evidentemente como grupos de identidade própria, em nome de carismas específicos, porém, muitas vezes, em atitudes de isolamento ou de paralelismo eclesial em relação às Igrejas locais. Alguns seguem uma direção individualista, outros uma lógica comunitarista (Doc. n. 105; n. 77-83) e, em ambos os casos, orientam-se por uma espécie de magistério próprio, que dispensa os ensinamentos do Vaticano II, do magistério papal e dos magistérios locais. A autorreferencialidade grupal dificulta uma ação consensual dos leigos não somente na sociedade, mas dentro da própria Igreja. A ação conjunta do laicato se mostra a cada dia mais difícil dentro e fora da Igreja. Aparecida não faz essa autocrítica do exercício concreto dos carismas distintos na vida laical.

\section{b) Do ponto de vista da fonte conciliar}

A temática do leigo tem um aspecto interno (a natureza eclesial do leigo) e um aspecto externo à Igreja (a ação no mundo). ${ }^{3}$ Como já foi exposto, Aparecida adota uma postura cristocêntrica como fundamento da vida e da ação eclesiais. Porém, esse cristocentrismo vincula-se ao mundo, operacionalizado por uma ação eclesiocêntrica. O leigo focado por Aparecida é um sujeito eclesial que atua no mundo. A ação vai da Igreja para o mundo: o sujeito eclesial é o sujeito social.

Não restam dúvidas que essa teologia do laicato supera os dualismos e cobra coerência do cristão no sentido mais genuíno do Evangelho. Mesmo

\footnotetext{
${ }^{3}$ Análise completa sobre a definição de leigo no Vaticano II: SCHILLEBEECKX, 1965, p. 981-1000.
} 
que verdadeira, essa teologia expressa somente um lado da questão do laicato. É possível olhar em outra direção: de fora para dentro da Igreja, dos leigos sujeitos históricos sem vínculos eclesiais que atuam no mundo. Nem todo sujeito social é um sujeito eclesial. Aliás, a imensa maioria dos leigos se encontra nessa condição, embora professe fé e até mesmo se declare cristão ou católico. Se a teologia do leigo se encontra resolvida desde o Vaticano II, não se pode dizer o mesmo de uma teologia da laicidade. A Igreja é verdadeiramente de Cristo, mas Cristo não é da Igreja. Aparecida é carente de uma visão crística do mundo, de uma cristologia das realidades terrestres, como propôs o Vaticano II. Há quem possa afirmar que careça de uma pneumatologia que permita encontrar na história humana a salvação de Deus em marcha. Nesse ponto, a presença do leigo no mundo, para além das referências eclesiais, é um déficit visível no Documento (CONGAR, 1965, p. 1001-1017). Essa dimensão desenvolvida no Capítulo III da Constituição Gaudium et spes permite falar da ação do leigo no mundo como uma consagração do mundo, precisamente em suas atividade profissionais (GS, n. 36); permite também ler teologicamente a ação laical - e até laicista (GS, n. 28 e 92) - dos artífices da cultura, da ciência e da tecnologia no mundo; reconhece nessas atuações a presença do Criador que conduz a história para o seu acabamento, para além de nossa visão imediata (GS, n. 34 e 57). A maioria esmagadora dos homens das ciências, das artes e da política não exerce um ministério leigo confessional, porém em muitos casos o fazem como homens de boa vontade, como cristãos anônimos ou, então, até mesmo com ateus e inimigos da Igreja, mas com os quais a Igreja pode dialogar e até mesmo aprender, como ensina o Vaticano II nas páginas conclusivas da Gaudium et spes:

O desejo de tal diálogo, que é guiado somente pelo amor à verdade, observada a devida prudência, de nossa parte não exclui ninguém, nem os que, honrando os bens admiráveis do engenho humano, contudo não admitem ainda o seu Autor, nem aqueles que se opõem à Igreja e a perseguem de várias maneiras (n. 92).

A laicidade é uma condição social, política e cultural da vida humana no momento histórico em que se encontra; condição que não terá retorno e nem acolherá de modo direto ou explícito a presença da Igreja como mestra ou como sujeito político principal. O diálogo em prol de causas vitais para a humanidade constitui, por certo, um caminho viável e necessário, onde o diálogo e a solidariedade se mostram como possibilidades bem-vindas e urgentes. Há que recuperar urgentemente uma visão teológica do processo histórico e exercitar a leitura dos sinais dos tempos em relação às alteridades culturais, políticas e religiosas que constituem a vida da humanidade atual. A teologia do leigo, Igreja no coração do mundo e mundo no coração da Igreja (DAp, n. 209), pede uma teologia da laicidade como fundamento e sentido de sua ação na sociedade. No coração do mundo pulsa secretamente o coração do Ressuscitado que sustenta a história para além de nossas visões superficiais, estreitas e imediatas. 


\section{Considerações finais: frutos de Aparecida}

Um mapeamento completo da recepção da V Conferência nesses dez anos se mostra como desafio aos estudiosos nos próximos anos. Como diz de modo realista o Papa Francisco, os documentos da Igreja já não causam o mesmo entusiasmo como no passado (EG, n. 25). Por certo, o Documento de Aparecida não teve a recepção entusiasta de Medellín e mesmo de Puebla naquele contexto continental. Nesse sentido, parece ser mais fácil ver em Aparecida um ponto de chegada de uma tradição eclesial latino-americana, do que um ponto de partida vigoroso, muito embora a chamada ao entusiasmo evangelizador seja sua tônica. Aparecida constitui o último elo da tradição do magistério latino-americano, elo que liga do ponto vista diacrônico com as demais Conferências e do ponto de vista sincrônico com outros ensinamentos eclesiais; ele que permite ler, na condição de última palavra, os ensinamentos anteriores e outros ensinamentos atuais. Nesse sentido, Aparecida é uma palavra atual que busca encarnar-se em nossas realidades; é semente que quer produzir frutos e fecundar a vida eclesial. Sabendo que o tempo é superior ao espaço (EG, n. 222), a Igreja semeia e aguarda os frutos, dos quais a colheita nem sempre é imediata. De fato, os limites humanos da Igreja e da história atuais corroem as sementes lançadas por Aparecida e abafam suas germinações.

Evidentemente, é possível ver frutos de Aparecida e, até mesmo, afirmar a possibilidade de sementes que germinam na Igreja e na sociedade. Todos são portadores dessas sementes em pleno tempo de semeadura e algumas colheitas. Um olhar cuidadoso sobre os planos pastorais das dioceses, paróquias e comunidades detectaria, certamente, elementos concretos de recepção dos ensinamentos referentes ao laicato. Os Documentos eclesiais repetem a regra de beber das últimas fontes do magistério, incluindo as orientações dos magistérios locais. Essa recepção teórica é visível, embora do ponto de vista prático não seja visível perceber mobilizações em torno de um projeto de Igreja que nasce de Aparecida. No tocante ao laicato, permanece válida a convocação de João Paulo II na Exortação Christifideles laici de que "a maravilhosa 'teoria' sobre o laicato, expressa pelo Concílio, possa converter-se numa autêntica 'praxe' eclesial" (n. 2). Os déficits práticos permanecem na Igreja e, em alguns aspectos, indicam até mesmo um agravamento, apesar das Conferências latino-americanas reproduzirem com fidelidade e criatividade a teologia do Vaticano II, buscando nela respostas e aprofundamentos a partir das realidades em que aconteceram. Persiste ainda uma dicotomia entre cleros e leigos, persiste uma cultura clerical que atravessa e molda as práticas e os sujeitos eclesiais, e persistem e crescem espiritualidades leigas que separam a Igreja da sociedade, a fé da vida.

Contudo, cabe destacar aqui dois frutos de Aparecida visíveis na Igreja atual. O primeiro deles é o próprio Papa Francisco: o fruto inesperado e 
mais robusto, possibilidade imediata de colheita fecunda e promessa de renovação para a Igreja. Sem esgotar esse dado grande e complexo, podem-se verificar alguns pontos que vinculam Francisco à Aparecida. As ocorrências do Documento de Aparecida em seus ensinamentos indicam essa recepção natural da V Conferência pelo Papa latino-americano e redator do texto final. ${ }^{4}$ A Igreja em saída é uma categoria eclesial e eclesiológica que nasce das sementes de Aparecida: a Igreja missionária e em reforma de si mesma. Nessa moldura teológico-pastoral, o leigo tem sido objeto de consideração direta do Papa. Seja na noção de povo que estrutura sua eclesiologia e na convocação de todos os sujeitos eclesiais a participarem da reforma inadiável da Igreja, seja nas críticas severas ao centralismo eclesial e ao clericalismo ou, ainda, na convocação do laicato para a ação transformadora da história, é possível verificar uma continuidade entre Aparecida e o magistério de Francisco. Numa coincidência histórica inédita, uma expressão do magistério continental chegou ao magistério papal. Pode-se falar, nesse sentido, em continuidade entre as duas esferas de ensinamento eclesial. Contudo, Francisco não repete simplesmente as decisões de Aparecida; ao contrário, avança não somente pela estatura de seu ensinamento na condição de magistério papal, mas também na visão crítica: completa nesse sentido a autocrítica eclesial de que carece Aparecida e coloca em ação a renovação da Igreja convocada por Aparecida. Avança também no diálogo com as ciências e com os homens de boa-vontade na Encíclica Laudato Sí, bem como na consideração da subjetividade do leigo, como consciência, autonomia e ação, na temática da família na Exortação Amoris laetitia. Pode-se afirmar que Aparecida está em marcha nos ensinamentos e nas posturas de Francisco. A Igreja está convocada a ser missionária, renovando a si mesma e renovando a sociedade, buscando no coração do Evangelho e no outro o Cristo vivo que a renova, experimentando a alegria de ser povo e de tocar na carne dos que sofrem.

Um segundo fruto pode ser verificado no Documento 105 da CNBB. ${ }^{5}$ A noção de sujeito que perpassa o conjunto da reflexão como eixo central tem sua ancoragem doutrinal e metodológica em Aparecida. No número 497 os bispos dizem querer: "Favorecer a formação de um laicato capaz de atuar como verdadeiro sujeito eclesial e competente interlocutor entre a Igreja e a sociedade e a sociedade e a Igreja" (497). O Documento 105 originalmente com a palavra sujeito em seu título entende o leigo nesses termos: como sujeito, ou seja, como agente eclesial consciente, autônomo e ativo que supera as práticas eclesiais comunitaristas e individualistas e constitui a comunidade eclesial como sujeito fundamental. O Documento 105 bebe diretamente de Aparecida, assim como dos ensinamentos do

\footnotetext{
${ }^{4}$ Na Exortação Evangelii gaudium: 12 ocorrências.

${ }^{5}$ CONFERÊNCIA NACIONAL DOS BISPOS DO BRASIL. Cristãos leigos e leigas na Igreja e na sociedade: sal da terra e luz do mundo (Mt 5,13-14). São Paulo: Paulinas, 2016.
} 
Papa Francisco. O ano nacional do laicato a ser celebrado em 2018 se insere nesse impulso eclesial de busca de uma tomada de consciência do leigo como sujeito eclesial, donde decorre atuação organizada dentro da Igreja e a atuação coerente nas estruturas sociais e políticas. Esse ano será celebrado em todo o país por meio de uma agenda de variadas atividades que pretendem envolver as Igrejas locais, as paróquias, as comunidades e os movimentos organizados.

Mas, toda recepção é um processo. A era Francisco e também as aplicações do Documento 105 levam adiante e aprofundam os ensinamentos de Aparecida sobre o laicato. Sabe-se que recepção não constitui aplicação automática de uma decisão ou orientação doutrinal ou pastoral e que não há também controle direto dos resultados dessa aplicação. Contudo, todo ensinamento da Igreja visa provocar mudanças; chama à conversão eclesial e pastoral, como insiste Francisco.

Aparecida permanece como ensinamento do magistério continental a ser recepcionado dez anos depois, não somente pelo valor normativo de última Conferência, fonte para se qual se volta de novo na busca de referências, mas por sua própria atualidade eclesial, histórica e eclesial. As práticas do leigo dentro e fora da Igreja, a autocompreensão e a organização, a espiritualidade e atuação social e política, podem revigorar-se nas orientações de Aparecida. A V Conferência ainda constitui um tesouro a ser explorado em suas orientações. $\mathrm{O}$ dom do discipulado e da missionaridade é uma tarefa que chama a todos nos tempos de crise em que vivemos.

\section{Referências}

BRIGHENTI, A. A desafiante proposta de Aparecida. São Paulo: Paulinas, 2007.

COMBLIN, J. O povo de Deus. São Paulo: Paulus, 2002.

COMPÊNDIO DO VATICANO II. Constituições, decretos, declarações. Petrópolis: Vozes, 1985.

CONFERÊNCIA GERAL DO EPISCOPADO LATINO-AMERICANO. Conclusões de Puebla. São Paulo: Loyola, 1982.

CONFERÊNCIA NACIONAL DOS BISPOS DO BRASIL. Apostolicam actuositaten: sobre o apostolado dos leigos. Brasília: CNBB, 2013. (50 anos do Concílio Vaticano II).

. Cristãos leigos e leigas na Igreja e na sociedade: sal da terra e luz do mundo (Mt 5,13-14). São Paulo: Paulinas, 2016.

CONGAR, Y. M-J. Os leigos e a "consecratio mundi". In BARAÚNA, G. A Igreja do Vaticano II. Petrópolis: Vozes, 1965 der, 1966.

. Os leigos na Igreja: escalões para uma teologia do laicato. São Paulo: Her- 
CONSELHO EPISCOPAL LATINO-AMERICANO. Conclusões de Medellín. Petrópolis: Vozes, 1973.

DOCUMENTO DE APARECIDA. Texto conclusivo da $V$ Conferência Geral do Episcopado Latino-americana e do Caribe. Brasília/São Paulo: CNBB/Paulus/Paulinas, 2007.

FRANCISCO, Papa. Exortação apostólica Evangelii Gaudium [...] sobre o anúncio do Evangelho no mundo atual. São Paulo: Paulinas, 2013.

- Carta encíclica Laudato si': sobre o cuidado da casa comum. São Paulo: Loyola, 2015. (Documentos do magistério).

. Exortação apostólica pós-sinodal Amoris Laetitia [...] sobre o amor na família. São Paulo: Loyola, 2017 (Documentos do magistério).

JOÃO PAULO II, Papa. Exortação apostólica Christifideles laici [...] sobre a vocação e missão dos leigos na Igreja e no mundo. São Paulo: Paulinas, 1988. (A voz do Papa, 119).

PASSOS, J. D. Concílio Vaticano II: reflexões sobre um carisma em curso. São Paulo: Paulus, 2014.

PIO XII, Papa. Encíclica Mistici corporis Christi: [...] sobre o Corpo Místico de Jesus Cristo e a nossa união nele com Cristo. São Paulo: Paulinas, 1965. (A voz do Papa, 19).

PONTIFÍCIA COMISSÃO PARA A AMÉRICA LATINA. O indispensável compromisso dos leigos na vida pública dos países latino-americanos. São Paulo: Paulinas, 2016.

SCHILLEBEECKX, E. A definição tipológica do leigo cristão conforme o Vaticano II. In BARAÚNA, G. A Igreja do Vaticano II. Petrópolis: Vozes, 1965.

VELASCO, R. A Igreja de Jesus: processo histórico da consciência eclesial. Petrópolis: Vozes, 1996.

Artigo submetido em 10.10.2018 e aprovado em 30.11.2018.

João Décio Passos é Doutor em Ciências Sociais pela Pontifícia Universidade Católica de São Paulo (PUC-SP), tem livre docência em Teologia pela mesma Universidade e nesta Instituição ocupa o cargo de professor associado. Orcid.org/0000-0003-4390-0423. E-mail: jdpassos@pucsp.br

Endereço: Rua Wanderley, 504 - Apto. 181

05/1.001 Perdizes - São Paulo 